\title{
Examining the Shifting Paradigms of Bhakti and Sanskrit Literature through Devotional Poetry of Jayadeva and Dadu
}

\author{
Dr. Aditi Swami ${ }^{1} \&$ Dr. Manju Dhariwal ${ }^{2}$ \\ ${ }^{1}$ Postdoctoral Researcher (Sociolinguistics, Indian Council of Social Science Research, New Delhi). \\ The LNM Institute of Information Technology, Jaipur, Rajasthan, India \\ ORCID id: 0000-0001-5950-6346. Email: aditirdswami@gmail.com \\ ${ }^{2}$ Professor, Department of Humanities and Social Sciences, \\ The LNM Institute of Information Technology, Jaipur, Rajasthan, India \\ ORCID id: 0000-0002-1579-1218. Email: manju@Inmiit.ac.in
}

\begin{abstract}
The wave of the Bhakti movement significantly affected India for over a period of twelve centuries. Considering that it left inerasable impressions on the history and culture of the land, this research paper argues that what only imbibed the feeling of pure devotion also became a tool in the hands of those who were desirous of radical religious, political and social changes. To prove this, the paper undertakes the translation of Dadu Dayal's Sanskrit compositions. Additionally, the paper also questions the very model of Bhaktikal (the Age of Devotional Literature), propagated by the scholars of Hindi Literature, which divides it into two distinct theological categories, Sagun and Nirgun. By examining the devotional poetry of Jayadeva Goswami and Dadu Dayal, and their sectarian positions, it demonstrates that the proponents of the two diametrically opposite schools of Bhakti did not always honour such a distinction for bhakti's spirit is above such schisms.
\end{abstract}

Keywords: Bhakti poets, Dadu Dayal, Jayadeva Goswami, Medieval Bhakti Literature, Nirgun Bhakti, Sagun Bhakti, Sanskrit Literature.

\section{Introduction}

One of the new factors in the religion of India from the fourteenth century up till the eighteenth century was perhaps the extraordinary rise of the vernaculars (J. N. Farquhar, 1984, p. 284). Foreign invaders destructed many Hindu schools, monasteries and temples which seriously weakened the Sanskrit scholarship (p. 284). Despite the weakening of the Sanskrit scholarship and the extraordinary rise of the vernaculars, the Sanskrit scholarship continued to thrive at places like Kashmir, Varanasi, Mithila in North Bihar and Nadia (Nabadwipa) in Bengal (Kashyap, 2015). It continued to influence the vernaculars which were more popular with the Nirgun bhakti poets like Kabir, Nanak, etc., who were either illiterate and had no access to formal education because of

This Open Access article is published under a Creative Commons Attribution Non-Commercial 4.0 International License (http://creativecommons.org/licenses/by-nc/4.0/), which permits non-commercial re-use, distribution, and reproduction in any medium, provided the original work is properly cited. For citation use the DOI. For commercial re-use, please contact editor@rupkatha.com. 
their social standing, or had acquired very little education. They preached the masses through self-composed poetry, created awareness in them, and facilitated them with alternative and affordable forms of worship. They often wandered places, gathered experiences and learnt about the plurality of the culture of the subcontinent. One such amongst them was Dadu Dayal (15441603), an influential bhakti poet and a Sufi saint of North-western India.

The information related to Dadu's birth, jati, marriage, etc. is not without controversy. Dadu's hagiographies propagate that in 1544, an infant was found flowing in the river Sabarmati by a childless, prosperous Brahmin named Lodhi Ram Nagar who was a cotton merchant. He and his wife, Vasibai, raised him as their own son and named him Dadu Dayal. 'Dadu' means brother and 'Dayal' means a compassionate one. Contrarily, scholars like Tara Dutt Gairola, William Gladstone Orr, Ronald Stuart McGregor, V. K. Subramanian, Monika Horstmann, etc. assert that Dadu was born in Ahmedabad in a Muslim family of cotton-carders.

Kashinath Upadhyaya (2010) explains that saints, who come to this world on a mission of mercy, are generally ignored by historians ( $p$ 17). Being wholly absorbed in their mission, they have hardly any time or interest in recording the events of their own lives (p. 17). So, the accounts of their lives remain largely shrouded in mystery, giving room for later controversies (p. 17). This precisely is true of Sant Dadu Dayal, Sant Kabir and many other saints (p. 17).

Dadu's disciples scribed his poetic compositions, collected them and compiled the scripture entitled, Dadu Anubhav Vani (1652) which means 'The Voice of Dadu's experience'. The first section of the scripture contains two thousand four hundred and eighty-nine saakhies categorised into thirty-seven angs (parts or chapters) dedicated to thirty-seven themes. A sakhi is mostly a two-line aphorism bearing testimony to the spiritual truth (Jagessar Das, 2015, p. 357). The term is derived from the term, sakshi, which means a 'witness' (p. 357). Like those of Kabir, Dadu's sakhis are also quoted for their poignant, concise and clear-sighted messages that are difficult to refute, and are aimed to remove hypocrisy in spiritual life and attain salvation (p. 357). The second section has twenty-seven chapters containing four hundred and forty-five shabds (prosodies) each one of which is assigned any one of the twenty-nine ragas. A manuscript of the scripture is worshipped at a place of worship and gathering called Dadu Dwara with all the operations of the Hindu idolatry like offering of flowers and food, arti, and singing of shabds and recitation of saakhies.

\section{Dadu's Sanskrit and Sanskritised Poetry}

The gist of Dadu's tenets is encapsulated in the two most sacred of his saakhies from the foremost chapter of the scripture (Monika Horstmann, 2021, p. 3). Like all the other ritualised acts in Dadu Panth, the sample sermon also begins with the Dadupanthi manglacharan, similar to the manglacharan verses of popular Advaita texts like Vedantsar (Thiel-Horstmann, 1992, p. 40). In case of a sermon, the manglacharan saakhies are followed by many other saakhies forming the extended manglacharan which praise the divine name, some of which are in Sanskrit (p. 40). From early on, the Dadupanthi authors have prefixed these to their works, and in live performances, every Dadupanthi sadhu will first of all recite the first of these saakhies or both (Horstmann, 2021, p. 3). They are in pseudo-Sanskrit, linguistically flawed as per the Paninean rules (p. 3). Their sacredness prevented them from being tampered with that otherwise was expected to happen at 
3 | Introduction

some point in a sect that over the centuries became more and more verse in the Sanskrit tradition (p. 3).

Some of Dadu's compositions are Sanskritised but the overall diction still remains a mixture of vernacular Hindi with some Rajasthani Bhashas and a few eastern dialects that seem to have been derived from the verses of eastern poet-saints (Ronald Stuart McGregor, 1984, p. 59). Usage of terms of Sanskrit origin was not of crucial importance to Dadu but it shows that Dadu was conscious of the existence of such comparable technical nomenclatures (McGregor, 1984, p. 59). Dadu's language is similar to Kabir's khichadi bhasha. It is difficult to ascertain as to what kind of education Dadu received since Dadu Panth's hagiographic tradition is a pole apart from the historical evidences about Dadu's life. But his extensive travelling for nearly six years before settling down at Rajasthan can be credited for the varied languages he used. It could be his dayto-day interaction with people from various backgrounds which reflects in his poetry. The following are his devotional Sanskrit and Sanskritised compositions:-

"Part of the Godlike-guru":-

दादू नमो-नमो निरंजनं, नमस्कार गुरुदेवतः।

वन्दनं सर्व साधवा, प्रणामं पारंगतः।।१।।

Dadu chants, 'Niranjan', pays homage to his Godlike-guru,

Reverence to the sages and obeisance to those who have transcended (1).

"Part of the Godlike-guru":-

परब्रहम परापरं, सो मम देव निरंजनं।

निराकारं निर्मलं, तस्य दादू वन्दनं।।२।।

The Ultimate and Transcendent Godhead is my Niranjan God;

To that Formless and Holy One, Dadu pays adoration (2).

"Part of Remembrance":-

दादू राम नाम जलं कृत्वा, स्नानं सदा जित:।

तन मन आत्म निर्मलं, पंच-भू पापं गत:।|६०।|

Dadu: Presuming Raam's name as holy water, always bathe in it!

It purifies the body, mind and soul, and makes the sins, caused by the five elements, vanish (60).

"Part of Remembrance":-

दादू उत्तम इन्द्री निग्रहं, मुच्यते माया मन:।

परम पुरुष पुरातनं, चिन्तते सदा तनः।|६१।।

Dadu: A good sadhaka represses one's senses and liberates one's mind from maya;

His body always meditates on the Ultimate and Immemorial Being! (61)

"Part of Remembrance":- 
दादू निर्गुणं नामं मयी हृदय भाव प्रवर्ततं।

भरमं करमं किल्विषं, माया मोहं कंपितं।।७८।।

कालं जालं सोचितं, भयानक यम-किंकरं।

हर्ष मुदितं सद्गुरु, दादू अविगत दर्शनं।|७९।।

Dadu: The heart fervently inclines to the Nirgun God's name,

So delusion, karma, sin, maya and attachments tremble (78).

While one imagines the snare of time or death, and the terrifying Yama,

Dadu rejoices and delights with his Sadguru, and beholds the Imperceptible One's darshan (79).

"Part of Maya":-

दादू गतं गृहं, गतं धनं, गतं दारा सुत यौवनं।

गतं माता, गतं पिता, गतं बन्धु सज्जनं।

गतं आपा, गतं परा, गतं संसार कत रंजनं।

भजसि भजसि रे मन, परब्रहम निरंजनं।|४७।|

Dadu: House and wealth depart; depart one's wife, youth and son;

Departs one's mother; departs one's father; depart one's friends and gentlemen;

Departs one's ego; depart the extrinsic elements; departs the whole world; why do you feel happy?

O heart, chant! Chant the Ultimate Godhead, Niranjan! (47)

"Raga Ramkali":-

Roopak Taal, Shabd 212:-

इहै परम गुरु योगं, अमी महारस भोगं। टेक।।

मन पवना स्थिर साधं, अविगत नाथ अराधं, तहँ शब्द अनाहद नादं।।१।।

पंच सखी परमोधं, अगम ज्ञान गुरु बोधं, तहँ नाथ निरंजन शोधं।।२।।

सद्गुरु मांहिं बतावा, निराधार घर छावा, तहँ ज्योति स्वरूपी पावा।।३।।

सहजैं सदा प्रकाशं, पूरण ब्रहम विलासं, तहँ सेवक दादू दासं।।४।।

Only here is the Ultimate Guru's yoga and the consumption of the supreme ambrosial nectar (chorus).

Stabilising your mind and breaths, worship the Imperceptible Nath! There's an unending nad of holy words (1).

The five friends of the senses rejoice when the guru imparts the unfathomable knowledge; I search for the Niranjan Nath there (2).

The Sadguru indicated the shelter of that independent home within where the Embodiment of the Divine Light is found (3).

Where the thorough Absolute revels and the sahaja light eternally prevails, there lives the servitor and bondsman Dadu (4). 
5 | Jayadeva and his Stance as a Bhakti Poet

These examples clearly show that despite not being well-versed in Sanskrit, it was perhaps Dadu's penchant for communicating in various tongues that resulted in his Sanskrit or awkward Sanskritised poetry.

In the context of Northern India, Sanskrit had long enjoyed a dominant position for it was the language of the ruling class. Brahmins, who were its uncontested litterateurs and custodians, had a monopoly over it. But instead of feeling humbled by its status or intimidated by the power of its speakers and knowers, Dadu brought it to his own use just as he preferred. While bhakti poets all over India, especially, from lower jatis, were trying to usurp the position of Sanskrit and the institutions associated with it by composing literature in the vernaculars of that time, Dadu challenged the hegemonic usage of this language. Even the likes of Mirabai (c.1498-c.1546), Goswami Tulsidas (1532-1632), Raskhan (1548-1628), Rahim (1556-1627), etc., who hailed from the upper strata of the society, chose vernaculars for their compositions. Dadu's stance can be contrasted against that of Goswami Tulsidas (1532-1623) who, despite being a Brahmin, did not disturb the original Sanskrit description of the month of Shravan in his own Awadhi work, Ramcharitmanas, and copied it just as it was in Valmiki's Ramayan. Dadu's position can be contrasted against that of Dnyaneshwar (1275-1296) too, who translated the Bhagwad Gita from Sanskrit to Marathi and compared himself to a tiny titibha bird trying to sound ocean's depth. However, Dnyaneshwar lived more than two centuries before Dadu's birth but Dadu's actions were still much ahead of his own times. By composing a few Sanskrit and Sanskritised verses and prosodies, Dadu was undoubtedly in a mood to challenge the authority of Brahmins and that of the ruling class that supported such hegemony.

On the other hand, by doing so, Dadu tried to impress and influence his audiences who were mostly the uneducated masses belonging to lower classes. He presented himself as someone intellectually at par with the religious gurus of his era, an act to divert the masses from the traditional system of religion which often favoured jati hierarchy and several other forms of distinctions. He tried to demonstrate that Sanskrit was not the forte of the upper class alone and if preaching in this language could make someone sound holier, then so be it. Dadu can be called a mystic with a religious vocation (McGregor, 1984, p. 58). His saakhies show his interest in systematising a theology to give an air of coherence to his preachings (p. 58). They are more homiletic and suggestive of a person of religion speaking to his followers (p. 58). Dadu's diction and the rhyme scheme of his Sanskrit poetry evoked radical resonances in the audiences of his poetic inventory and also gained him a large number of followers.

\section{Jayadeva and his Stance as a Bhakti Poet}

Jayadeva Goswami (c.1170-c.1245) was a Vaishnavite Brahmin. The inscriptions at Lingaraja Temple (Bhubaneswar, Odisha) and Madhukeshwara Temple (Banavasi, Karnataka), read and interpreted by Dr. Satyanarayana Rajguru, shed some light on his early life (PoemHunter, 2012, p. 1). They reveal that Jayadeva was a member of the teaching faculty of the school at Kurmapataka (near Konark, Odisha) where he had studied in Sanskrit and gained an experience in poetry, singing and dancing (PoemHunter, 2012, p. 1).

His work, the Gitagovinda, considered among the finest examples of Sanskrit poetry and an important text in the Bhakti movement, became popular throughout India within a short period of its composition because it was regularly performed in the Jagannath temple of Puri 
(PoemHunter, 2012, p. 2). This lyrical ballad is organized in twelve chapters. Each chapter is divided into twenty-four divisions called Prabandhas. Each prabandha contain couplets grouped into eights called Ashtapadas. This epic poem depicts the divine love of Krishna, an avatar of Vishnu, and his consort, Radha, who is greater than Hari (PoemHunter, 2012, p. 1). Jayadev is the first poet who mentioned Lord Jagannath as Radha and Krishna mingled together (Somanath Jena, 2008, p. 1).

What is surprising is that though Sikhism condemns idolatry and preaches devotion toward the non-incarnate, formless and eternal Absolute, there is an exception to this fact because the Guru Granth Sahib includes Jayadeva's compositions from the Gitagovinda. Guru Nanak never mentions Jaidev in his works (Pashaura Singh, 2003, p. 121). Still, records narrate how the Gitagovinda had a profound influence on him during his visit to Puri (PoemHunter, 2012, p. 2). Guru Arjan Dev, the fifth Guru, who was responsible for making the first canonical text of the Adi Granth (1604), included two of Jaidev's hymns in the Adi Granth (p. 122). The Sikh tradition maintains that the author of these two hymns in the Adi Granth had also authored the Gitagovinda (p. 119-20).

S. N. Chatterji notes that Jaidev's poem in "Raga Gujari" is in Sanskrit but is corrupted by scribes who read it in a vernacular eastern Indian pronunciation with a number of Apabrahmsa and vernacular forms (as cited in Singh, 2003, 125). It could have been wholly in Apabhramsa and then badly Sanskritised with vernacular Bangla or an eastern Indian pronunciation showing through the spelling which was further modified in the Gurumukhi script of the Granth (Singh, 2003, p. 125). Probably, it underwent certain linguistic alterations during the process of oral transmission (p. 125). C. Shackle pinpoints that it has genuine Sanskritic instrumental forms which help his hymn appear a little more like garbled Sanskrit than divergent Sahaskriti (as cited in Singh, 2003, p. 125). Earnest Trumpp notes that it's a queer mixture of Sanskrit and the vulgar tongue (as cited in Singh, 2003, p. 125). Probably, the hymn was composed when the era of the classical Sanskrit poetry was on the decline and the new age of vernacular poetry was on the rise (Singh, 2003 , p. 125). And Jayadeva sang not only the 'swan-song of the age' that was passing away but also in the advent of a new age in the Indian literature, the 'Vernacular age' (Chatterji as cited in Singh, 2003, p. 125). The following hymn of Jayadeva in "Raga Gujari" is quoted from Sant Singh Khalsa's translation of the Granth--

In the very beginning, was the Primal Lord, unrivalled, the Lover of Truth and other virtues. $\mathrm{He}$ is absolutely wonderful transcending creation; remembering $\mathrm{Him}$, all are emancipated.1. Dwell only upon the beauteous Name of the Lord, the embodiment of ambrosial nectar and reality. Remembering Him in meditation, the fear of birth, old age and death will not trouble you.1.Pause. If you desire to escape the fear of the Messenger of Death, praise the Lord joyfully, and do good deeds. In the past, present and future, $\mathrm{He}$ is always the same; $\mathrm{He}$ is the embodiment of supreme bliss.2. If you seek the path of good conduct, forsake greed, and do not look upon other men's property and women. Renounce all evil actions and evil inclinations, and hurry to the Sanctuary of the Lord.3. Worship the immaculate Lord, in thought, word and deed. What is the good of practicing Yoga, giving feasts and charity, and practicing penance? 4 Meditate on the Lord of the Universe, the Lord of the Universe, $\mathrm{O}$ man; $\mathrm{He}$ is the source of all the spiritual powers of the Siddhas. Jaidev has openly come to Him; He is the salvation of all, in the past, present and future.5.1. 
Many Sikh interpreters translate the phrase, Git Govind, as 'Song of the Lord' in general terms, without paying much attention to the import of its original meaning (Singh, 2003, p. 142). Barbara Stoler Miller argues that the association of the author of the Gitagovinda with the Adi Granth that verses on the ground that 'the two mixed Prakrit-Apabhramsa verses attributed in the Guru Granth Sahib are characterised by the kind of abstract devotionalism which is not present in the Gitagovinda' is questionable (as cited in Singh, 2003, p. 120). Thus, it indicates that there are certain links of formal nature with the Gitagovinda as well as differences in major themes between the two texts (Singh, 2003, p. 147). Guru Ram Das, the fourth Sikh guru, mentions Jaidev for the first time in his works and repeatedly inspires his own audiences with the example of the celebrated Bhagats who achieved God-realisation through the transforming power of the divine Name (Singh, 2003, p. 122). His references point toward a high spiritual reputation which Jaidev enjoyed within the circles of the sants of Northern India (p. 122). The stress on divine amorous symbolism in the Gitagovinda may be understood by the Vaishnavas to transcend the sensual and domestic level in the context of temple worship (p. 147). The Sikh interaction with the Vaishnavas in the Punjab during the period of the early Sikh gurus is marked by clear-cut boundaries between the two traditions on the doctrinal level (p. 147). The Sikhs may have observed the Vaishnavas singing the Gitagovinda's songs in temple worship and appreciated the intensity of their devotion but they knew that their participation in the devotional singing of the gurus' hymns sets them apart from the Vaishnavas (p. 147). Still, a passionate carnal love is the central theme of this text which is intended for the courtly life and for the ecstatic life of the ardent devotee, which would be least acceptable to Guru Arjan Dev who was primarily compiling the scripture for the community of householders (p. 147). The hymns of Sagun Bhagats who emphasised worshipping, through image and myth, were least acceptable to Guru Arjan Dev (p. 147). His policy was to keep the Sikh tradition removed from the Vaishnava influence (p. 146). His selection logic favoured those poems which emphasize Nirgun religiosity and social equality, and conform to the Sikh gurus' line of thinking (p. 147). Passion undermines the very ideal upon which the household is based but the tone of Jaidev's Gujari hymn emphasises the renunciation of 'greed, coveting of one's neighbour's wife and all sinful desires' (p. 147). Jaidev's message in the Adi Granth is intended for the 'common people' leading the life of a householder (p. 147). The following is Khalsa's translation of Jayadeva's hymn in "Raga Maru":-

The breath is drawn in through the left nostril; it is held in the central channel of the Sushmanaa, and exhaled through the right nostril, repeating the Lord's name sixteen times. I am powerless; my power has been broken. My unstable mind has been stabilized, and my unadorned soul has been adorned. I drink the Ambrosial Nectar.1. Within my mind, I chant the Name of the Primal Lord God, the Source of virtue. My vision, that You are I are separate, has melted away.1.Pause. I worship the One who is worthy of being worshipped. I trust the One who is worthy of being trusted. Like water merging in water, I merge in the Lord. Says Jaidev, I meditate and contemplate the Luminous, Triumphant Lord. I am lovingly absorbed in the Nirvana of God.2.1

In terms of Jaidev's spiritual attainment, Guru Arjan Dev mentions in his dupada in "Raga Basant" that Jaidev had risen above his egoism. 
A sawaiya composed in praise of the First Mehl mentions that God's 'Glorious praises are sung by devotees Ravidas, Jaidev and Trilochan'. It indicates that Jayadeva had accepted God as the One who is devoid of anthromorphic features.

A sawaiya composed in praise of the Third Mehl mentions:-

'The understanding which Jaidev grasped, the understanding which permeated Namdev, the understanding which was in the consciousness of Trilochan and known by the devotee Kabir, by which Rukmangada constantly meditated on the Lord, O Siblings of Destiny, which brought Ambreek and Prahlad to seek the Sanctuary of the Lord of the Universe, and which brought them to salvation that sublime understanding has brought You to renounce greed, anger and desire, and to know the way.'

Here, the 'understanding' refers to God-realisation and the spiritual attainment of an individual wherein one transcends the sectarian and religious boundaries and affiliations and accepts the Absolute as a formless, eternal and non-incarnate God. Jayadeva's name also appears along with the other bhakti poets who had attained such an 'understanding'.

Upon taking a dynamic view of Jayadeva's life, it becomes clear that Jayadeva, in his later life, had become a Nirgun saint. The selection of Jaidev's hymns is not linked with his association with the Gitagovinda or the Vaishnava circles in anyway in his lifetime (Singh, 2003, p. 142). The image of Jayadeva which emerges from his hymns is that of a bhakti poet who believes in a nonincarnated God. From Lord Krishna's devotee, he became a devotee of the Supreme Lord. Like Namdev, Jaidev may have had different allegiances at different stages of his life (Singh, 2003, p. 142). Hence, he was both a Sagun Bhagat of the Gitagovinda and a Nirgun Sant of the Adi Granth who must have experienced both Nirgun and Sagun discourses at the Jagannath temple of Puri (p. 142). This region must have offered him with an opportunity of experimenting with different philosophies and experiences of life (Himadri Banerjee as cited in Singh, 2003, p. 142). So, it can be concluded that despite being a Sagun bhakti poet in his early stage of life, Jayadeva's devotion had transformed and his inclination towards the formless Supreme Self had deepened later.

\section{Dadu and his Stance as a Bhakti Poet}

The Nirgun-Sagun model was first popularised by the Hindi scholars like Ramchandra Shukla, Pitambar Dutt Barthwal and Parshuram Chaturvedi, and that Shukla was the first to propound the notion of Bhaktikal and divide it into two distinct theological categories namely Nirgun and Sagun (Rameshwar Prasad Bahuguna, 2009, p. 2-3). The radical Nirgun sects, founded in the names of the leading Nirgun preachers (Kabir, Dadu, etc.), were poles apart from the Sagun sects founded in the names of the Sagun preachers (Tulsidas, Surdas, etc.). This model also made the modern Western scholars of the last forty years hugely depend on the theories propounded by the Hindi scholars (Bahuguna, 2009, p. 4). Although, there is a clear distinction between the two types of schools in terms of practicing idolatry and expressing devotion towards God but what is undeniable is that such a distinction hardly mattered to the bhakti poets, as Dadu, who had no faith in sectarianism. There were differences in the theological learning of these schools. Yet, 'they all inherited a single, massive bhakti', and often breached this theological wall (John Stratton Hawley as cited in Bahuguna, 2009, p. 7). This very fact conforms to the cosmopolitan archetype that Bhakti exhibits. While it was a historical reality with sectarian and theological boundaries, this 
9 | Dadu and his Stance as a Bhakti Poet

distinction was not always honoured in the sant vanis, hagiographies and anthologies, and the alignments like the one between Namdev and Surdas also took place (Hawley as cited in Bahuguna, 2009, p. 13-14).

Dadu was also aware of such divides in his times but for him, only an unalloyed devotion towards the Absolute mattered whom he often addressed just as the Sagun bhakti poets addressed their chosen gods and goddesses. This line of division was not a rigid boundary for Dadu who overlooked, ignored and crossed it effortlessly. For him, it was a semi-permeable membrane between the two realms. Though he used the names of the gods and goddesses that are stereotypically associated with Sagun bhakti, Sagun bhakti, as a socio-religious practice, and its temporal aspects could not affect Dadu. Dadu may be called a Nirgun bhakti poet because he did not favour idolatry but his compositions do not conform to the Sagun and Nirgun stereotypes. For example, Shabd 7 - O Beloved! This lady has adorned herself. Now, meet her early, Banwari; Shabd 12 - O Keshav! Don't forsake me; Shabd 15 - O Gusain! How can we, your subjects, survive if you abandon us, o Almighty Lord? Shabd 65 - O brother! I engrossed in the One when the true wisdom ensued on meeting Mohan; Shabd 81 - O Govind! Your name is my life; Shabd 90 Foremost, I worship the Supreme Ganapati; Shabd 91 - I've acknowledged Hari as my precious wealth; Shabd 118 - O, my respectable Nath! Make me chant your name and preserve the gem of Raam in heart; Shabd 133 - O Madhava! Restrain, restrain my mind; Shabd 182 - All hail! Jagdish, you're Almighty; Shabd 290 - O Generous One! My bounteous Kanha; Shabd 339 - O Jagannath! Raam has been forgotten; Shabd 372 - Manmohan is in my heart; etc. express Dadu's devotion towards God to whom he referred to variously. Though Dadu believed that God is devoid of anthromorphic attributes and cannot be described perfectly but by referring to the Sagun gods, Dadu mentioned as many attributes as he could to describe God as much as possible. Dadu's compositions conveniently navigate between the regions of Sagun and Nirgun forms of worship through the river of pure devotion.

Though the history of Medieval Bhakti Literature does indicate an ideological and a theological conflict between the Nirgun sants and Sagun Vaishnavas over Raam's identity, Dadu's perception of Raam or Hari was that of a non-incarnate and formless being. Still, never did he shy away from expressing his devotion towards the Absolute by acknowledging Him even in the Sagun gods. Dadu's stand on the Nirgun and Sagun divide becomes clearer through his following saakhi and shabd:-

"Part of Remembrance":-

Dadu's Raam is unfathomable; none can understand the Imperceptible One;

Why talk of nirgun and sagun? Delay not in practicing remembrance! (17)

Raga Ramkali, Choutaal, Shabd 198:-

Only he finds the path to the Beloved to whom it is revealed. (refrain)

Some follow the path of Hindus, some follow that of Turks and some follow some other faith.

Some follow the path of Sufis, some are Sevada Jains and some are sannyasis. (1) Some follow the path of yogis, some are Jangamas and some are the worshippers of Shakti.

Some are Telis; some are Kapadis while some consider many. (2) 
Some founded their own sects but I know only one path.

Dadu only recognises Him who created this world.

I'm a traveller on the path to the Infinite. No one else does my heart like.

Dadu himself insisted that his religious path was beyond caste and creed, and this principle remained valid, albeit at times, obscured in Dadu Panth - the sect that was formed after his death and institutionalised by Dadu's fourth generation successor, Jayatram (1693-1732).

\section{Conclusion}

It would be unjust to deal with as great an author as Jayadeva and the text, the Gitagovinda, at a primary level alone. The Gitagovinda presents a consecrated account of divine love play in terms of human passion (Gadadhar Mahopatra, 2008, p. 22). While outwardly, it describes the love, separation, longing and union of Radha and Krishna, metaphysically, it connotes the yearning of the atman for the mystique union with the Paramatman (p. 22). Its spiritual essence, mystical imports, sensual overtones, aesthetic description and lyrical fluid have baffled critic, bewildered scholars, mystified saints, charmed lovers, enlightened devotees and influenced religious faiths, cultures, traditions, literature, poetics, music and dance forms (p. 22). It inspired creativity in the form of art, architecture, painting and sculpture, and involved people sentimentally with its dramaturgy and poetics that are skillfully crafted to touch the innermost core of the heart and inspire the noblest emotions (p. 22).

The very fact that Jayadeva is celebrated as a bhakti poet in Sagun as well as Nirgun traditions and inscriptions about whose early life are found in the temples of Shiva demonstrate how his devotion had transcended the Vaishnavite sectarian affiliation and moved towards a higher realm of spiritualism.

Dadu also perceived his soul as the lover of his Beloved, the Absolute. So at a primary level, while many of his compositions depict a lovelorn-maid pinning for her beloved, on the secondary level, they indicate the spiritual yearning of a soul for an eternal union with God. Dadu combined the nonviolence of the Vaishnavas, the self-control of yogis and the love of Sufis (J. P. Srivastava, 1999, p. 530). He laid stress on the oneness of God and Preceptor, the importance of the name of Raam and self-dedication, the falsity of the world and illusion of worldly-belongings, the love for the nonmanifest, an intense feeling of love sickness, the unity of body and universe, and the realisation of the eternal truth (p. 530-31). Dadu rejected the jati hierarchy and all the social conventions based on it. Like his predecessor, Kabir, he also championed new social values which promised equality to everyone irrespective of one's social status and background.

So, it is evident that the devotional poetry of Jayadeva and Dadu simultaneously give voice to varied religious beliefs and preach all to remain away from socio-religious schisms.

\section{Acknowledgement}

This paper forms a part of the postdoctoral research in Sociolinguistics (2019-present) entitled, "Complete English Translation of Dadu Dayal's Dadu Anubhav Vani. Impact of Socio-Lingual and Socio-Cultural Milieu in Contemporary India", undertaken by Dr. Aditi Swami under the supervision of Dr. Manju Dhariwal. This research is being funded by ICSSR, New Delhi. 


\section{References}

Bahuguna, R. P. (2009). Conflict and assimilation in Medieval North Indian Bhakti: an alternative approach. In Beyond Theological Differences SAP (UGC) Programme. essay, Department of History and Culture, Jamia Millia Islamia, New Delhi.

Dayal, D. (2012). Shri Daduvani. (Swami Narayandas, Ed.). Shri Dadu Dayalu Mahasabha.

---. (2010) Dadu: The Compassionate Mystic. (K. N. Upadhyaya, Trans.), 4th ed., Radha Soami Satsang Beas.

Farquhar, J. N. (1984). An Outline of the Religious Literature of India. Motilal Banarsidass.

Goswami, J. (2012, September). Classic Poetry Series: Jayadeva - the poems. PoemHunter.com. https://www.poemhunter.com/i/ebooks/pdf/jayadeva_2012_9.pdf.

Horstmann, M. (2021). Preface. Bhakti and yoga: a discourse in seventeenth-century codices (1st ed.). Primus Books.

Jena, S. (2008, May). Miracles in the Life of Sri Jayadeva. (S. S. Panda, Ed.). Orissa Review, LXIV(10), 1-3.

Kabīr, Das, J., \& Dube, C. (2015). Sakhis. The complete Bijak of Kabìr: guru Kabìr's mystical teachings on god-realization. New Age books.

Kashyap, D. (2015, October 1). 4 Medieval Centres of Higher Education for Hindus. Your Article

Library. https://www.yourarticlelibrary.com/hindu-philosophy/4-medieval-centres-of-higher-educationfor-hindus/63495.

Khalsa, S. S. (2007). Siri Guru granth sahib (3rd ed., Vol. 1). Hand Made Books.

Mahopatra, G. (2008, May). Depiction of Tangible and Intangible Elements of Nature in Gita Govinda Kavyam. (S. S. Panda, Ed.). Orissa Review, LXIV (10), 22-27.

McGregor, R. S. (1984). Dadu. A History of Hindi Literature. Otto Harrassowitz Verlag.

Singh, P. (2003). Bani Sri Jaidev Ji Ki. The Bhagats of the Guru Granth Sahib: Sikh self-definition and the Bhagat Bani. Oxford University Press.

Srivastava, J. P. (1999). Poems and Couplets: Dadu Dayal. Medieval Indian literature: an anthology. (Ayyappapaniker, Ed.). Sahitya Akademi.

Thiel-Horstmann, M. (1992). An Oral Theology: Dadupanthi Homilies. Devotional Literature in South Asia. (R. S. McGregor, Ed.). Cambridge University Press.

\section{Authors' Note}

The first author, Dr. Aditi Swami, did M. Phil. and Ph. D. (Comp. Lit.) from Central University of Gujarat, Gandhinagar. Her areas of interest include British Literature, Feminist Studies, Gender Studies, Indo-Anglian Literature, Medieval Bhakti, Postcolonial Studies, Sikh Studies, Sufi Studies and Translation Studies.

The co-author, Dr. Manju Dhariwal, teaches English language and literature courses to at the LNM Institute of Information Technology. She has published articles in reputed journals and guided 
12 | Rupkatha Journal, Vol. 13, No. 4, 2021

Ph.D. research. She has co-authored the book, Mastering Communication Skills and Soft Skills (2015), published by Bloomsbury India. Modernist Studies, Gender and Feminist Literature, and Indian Writing in English are her areas of interest. 